\title{
Pengaruh Dosis Kompos Kulit Bawang Merah Terhadap Pertumbuhan Sawi Samhong (Brassica rapa)
}

\author{
Andreas Thata Jatra, Luluk Syahr Banu dan Siti M. Sholihah \\ Program Studi Agroteknologi Fakultas Pertanian Universitas Respati Indonesia \\ Email: luluksyahrbanu@gmail.com
}

\begin{abstract}
ABSTRAK
Sawi samhong merupakan sayuran yang mempunyai nilai ekonomis dan bergizi tinggi dibandingkan dengan beberapa jenis vareitas sawi lainnya. Salah satu upaya peningkatan produktivitas budidaya sawi samhong adalah dengan pemupukan. Penggunaan kompos kulit bawang merah sebagai pupuk organik pada budidaya tanaman sawi samhong, berperan untuk memperbaiki sifat fisik, kimia tanah dan biologi tanah, meningkatkan pertumbuhan tanaman dan hasil panen, dan aman untuk dikonsumsi. Tujuan penelitian adalah untuk mengetahui pengaruh dosis kompos kulit bawang merah terhadap pertumbuhan sawi samhong dan mengetahui dosis kompos kulit bawang merah yang menghasilkan pertumbuhan terbaik pada sawi samhong. Penelitian dilaksanakan di Kelurahan Duri Kosambi, Kecamatan Cengkareng, Kota Jakarta Barat, pada bulan Juli sampai Agustus 2021. Rancangan yang digunakan dalam penelitian ini adalah Rancangan Acak Kelompok (RAK), dengan satu faktor (dosis kompos kulit bawang merah), yang terdiri atas empat perlakuan yaitu : D0 (0 gram/polibag), D1 (500 gram/polibag), D2 (1.000 gram/polibag) dan D3 (1.500 gram/polibag) diulang 6 kali. Variabel penelitian meliputi tinggi tanaman, jumlah daun, lebar daun, panjang daun dan bobot basah. Hasil penelitian menunjukkan bahwa perlakuan dosis kompos kulit bawang merah berpengaruh nyata terhadap tinggi tanaman, jumlah daun, lebar daun, panjang daun dan bobot basah. Perlakuan dosis kompos kulit bawang merah 1.500 gram/polibag memberikan hasil terbesar pada tinggi tanaman $(27,20 \mathrm{~cm})$, jumlah daun $(13,70$ helai), lebar daun $(13,70 \mathrm{~cm})$, panjang daun $(24,20 \mathrm{~cm})$, dan bobt basah $(101,67 \mathrm{gr})$.
\end{abstract}

Kata kunci: pupuk organik, kompos, limbah kulit bawang merah, sawi samhong

\section{ABSTRACT}

Samhong mustard is a vegetable that has high economic and nutritional value compared to several other mustard varieties. One of the efforts to increase the productivity of samhong mustard cultivation is fertilization. The use of onion peel compost as organic fertilizer in the cultivation of mustard greens has a role in improving the physical, chemical and biological properties of the soil, increasing plant growth and crop yields, and is safe for consumption. The purpose of the study was to determine the effect of the dose of onion peel compost on the growth of samhong mustard greens and to determine the dose of onion peel compost that produced the best growth in samhong mustard greens. The study was carried out in Duri Kosambi Village, Cengkareng District, West Jakarta City, from July to August 2021. The design used in this study was a Randomized Block Design (RAK), with one factor (dose of onion peel compost), which consisted of four The treatments were: D0 (0 grams/polybag), D1 (500 grams/polybag), D2 (1,000 grams/polybag) and D3 (1,500 grams/polybag) repeated 6 times. The research variables included plant height, number of leaves, leaf width, leaf length and wet weight. The results showed that the dose of onion peel compost treatment had a significant effect on plant height, number of leaves, leaf width, leaf length and wet weight. The treatment of onion peel compost dose of 1,500 grams/polybag gave the greatest yield on plant height $(27.20 \mathrm{~cm})$, number of leaves (13.70 pieces), leaf width $(13.70 \mathrm{~cm})$, leaf length $(24.20 \mathrm{~cm})$, and wet weight $(101.67 \mathrm{~g})$.

Keywords: organic fertilizer, compost, onion peel waste, mustard samhong 


\section{PENDAHULUAN}

Sayuran merupakan salah satu menu dari komponen makan sehat, yang permintaannya semakin meningkat seiring dengan kesadaran masyarakat tentang kesehatan. Di antara banyak tanaman sayur yang dibudidayakan, sawi samhong adalah salah satu komoditas sayuran yang mempunyai prospek yang tinggi. Budidaya sawi samhong selain mudah dibudidayakan lebih disukai karena umur panennya relatif cepat. Budidaya sawi samhong merupakan usaha yang cukup menjanjikan bagi petani karena tanaman ini sudah dapat dipanen setelah berumur 5 minggu setelah panen [1]. Kandungan yang terdapat pada sawi samhong ini adalah protein, lemak, karbohidrat, $\mathrm{Ca}, \mathrm{P}, \mathrm{Fe}$, Vitamin A, Vitamin B, dan Vitamin C. Manfaat sawi samhong sangat baik untuk menghilangkan rasa gatal ditenggorokan pada penderita batuk, serta memperbaiki dan memperlancar pencernaan [2].

Pertumbuhan pada sawi samhong dipengaruhi oleh ketersedian unsur hara makro dan mikro, dimana jika ketersedian unsur hara tidak optimal, maka harus dilakukan pemupukan. Sawi samhong tumbuh baik pada tanah dengan kandungan nitrogen yang tinggi. Pemberian pupuk dengan unsur $\mathrm{N}$ pada tanah dapat meningkatkan tinggi tanaman sawi samhong sebesar $2,4 \mathrm{~cm}$ pada setiap pengamatan, dan berat basah tanaman sebesar 1,3 g. Selain unsur $\mathrm{N}$ unsur $\mathrm{K}$ juga berperan penting dalam pertumbuhan tanaman [3].

Petani sawi samhong pada umumnya menggunakan pupuk berupa pupuk padat dan pupuk cair baik itu organic dan anorganik. Penggunaan pupuk kimia memang dapat meningkatkan kandungan unsur hara makro pada tanah, namun tentu saja penggunaannya dapat menimbulkan efek samping negatif. Efektivitas penggunaan pupuk kimia tidak bertahan lama karena penggunaan pupuk kimia secara terus menerus dapat menyebabkan perubahan struktur tanah, pemadatan, kandungan unsur hara dalam tanah menurun dan pencermaran tanah [4].

Pada saat ini banyak petani yg beralih menggunakan pupuk organik untuk kegiatan budidaya sawi samhong. Pupuk organik merupakan hasil dekomposisi bahan-bahan organik baik tumbuhan kering (humus) maupun limbah dari kotoran ternak yang diurai (dirombak) oleh mikroba hingga dapat menyediakan unsur hara yang dibutuhkan tanaman untuk pertumbuhan dan perkembangan tanaman [5]. Pupuk organik dapat meningkatkan anion-anion utama untuk pertumbuhan tanaman seperti nitrat, fosfat, sulfat, borat, dan klorida serta meningkatkan ketersediaan hara makro 
untuk kebutuhan tanaman dan lebih aman karena residunya kecil dan aman bagi kesehatan manusia dan lingkungan [6].

Ada beberapa pupuk organik yang dapat dipakai untuk menanam tanaman sawi samhong seperti pupuk kandang, kompos dan limbah, yang dapat berguna menambah unsur hara [7]. Untuk budidaya tanaman sawi samhong dengan pemberian pupuk organik yang dapat diolah dari bahan limbah organik yang ada di lingkungan seperti limbah kulit bawang merah. Tingginya produksi bawang merah pada sektor pertanian menyebabkan meningkatkan limbah yang dihasilkan dari produksi bawang merah. Saat ini untuk pengolahan limbah bawang limbah kulit bawang juga dapat bermanfaat bagi kehidupan. Menurut hasil penelitian yang dilakukan oleh Benitez dan para ilmuwan dari Cranfield University, Inggris, mereka mengemukakan bahwa kulit coklat bawang dapat digunakan sebagai bahan fungsional tinggi serat (terutama jenis non larut) dan senyawa fenolik, seperti quercetin dan flavonoid lain (metabolit tanaman dengan sifat obat). Selain itu limbah kulit bawang merah bisa digunakan sebagai pupuk. Hal ini sejalan dengan penelitian dosis kompos kulit bawang merah terhadap tanaman selada dan terung pada sistem polikultur menunjukkan berpengaruh tidak nyata pada pertumbuhan namun penggunaannya efektif untuk masing-masing pertumbuhan tanaman selada ataupun terung [8] .

Berdasarkan uraian diatas perlu dilakukan penelitian untuk mengetahui Penggunan pupuk kompos kulit bawang merah digunakan pengaruh pemberian pupuk kompos dari kulit bawang merah terhadap pertumbuhan tanaman sawi samhong.

\section{METODE PENELITIAN}

Pelaksanaan kegiatan penelitian ini dilakukan di Kecamatan Cengkareng, Jakarta Barat, pada bulan Juli sampai Agustus 2021. Bahan dan alat yang diperlukan dalam penelitian adalah adalah benih tanaman sawi samhong, kompos kulit bawang merah, tanah top soil, arang sekam, dan air, cangkul, mistar, gembor, dan polibag.

Rancangan yang digunakan dalam penelitian ini adalah Rancangan Acak Kelompok (RAK), dengan satu faktor (dosis kompos kulit bawang merah), yang terdiri atas empat perlakuan yaitu : DO $(0$ gram/polibag), D1 (500 gram/polibag), D2 (1.000 gram/polibag) dan D3 (1.500 gram/polibag) diulang 6 kali. Pelaksanaan awal penelitian yaitu pembuatan kompos kulit bawang merah. Kulit bawang merah sebanyak $20 \mathrm{~kg}$ dengan air 1 liter dan EM4 $20 \mathrm{ml}$. Bahan kulit bawang merah dan larutan EM4 diaduk hingga tercampur merata. Bahan yang sudah tercampur kemudian ditutup dan ditunggu 1 minggu sampai menjadi kompos. Kompos 
dimasukkan dalam media tanam sesuai dengan perlakuan awal tanam da penanaman sawi samhong dilakukan hingga panen.

Variabel penelitian meliputi tinggi tanaman, jumlah daun, lebar daun, panjang daun dan bobot basah. Data yang diperoleh dari hasil penelitian kemudian ditabulasi dan dianalisis menggunakan Analisis Ragam (ANOVA) dan dilanjutkan dengan uji BNT 5\% apabila berbeda nyata.

PEMBAHASAN

Tabel 1. Hasil Uji BNT Pengaruh Dosis Kompos Kulit Bawang Merah Terhadap Tinggi Tanaman

\begin{tabular}{lccccc}
\hline \multirow{2}{*}{ Perlakuan } & \multicolumn{5}{c}{ Tinggi Tanaman $(\mathrm{cm})$} \\
\cline { 2 - 6 } & $1 \mathrm{MST}$ & $2 \mathrm{MST}$ & $3 \mathrm{MST}$ & $4 \mathrm{MST}$ & $5 \mathrm{MST}$ \\
\hline D0 (0 gr) & $2.6 \mathrm{a}$ & $4.7 \mathrm{a}$ & $8.2 \mathrm{a}$ & $12.2 \mathrm{a}$ & $14.8 \mathrm{a}$ \\
D1 (500 gr) & $2.7 \mathrm{a}$ & $5.7 \mathrm{~b}$ & $10.8 \mathrm{~b}$ & $16.3 \mathrm{~b}$ & $20.7 \mathrm{~b}$ \\
D2 (1.000 gr) & $2.7 \mathrm{a}$ & $6.0 \mathrm{~b}$ & $11.8 \mathrm{~b}$ & $18.8 \mathrm{c}$ & $24.8 \mathrm{c}$ \\
\multicolumn{1}{c}{ D3 (1.500 gr) } & $3.0 \mathrm{a}$ & $6.4 \mathrm{~b}$ & $13.8 \mathrm{c}$ & $21.0 \mathrm{~d}$ & $27.2 \mathrm{~d}$
\end{tabular}

Keterangan : Angka-angka yang diikuti huruf yang sama pada kolom yang sama berarti tidak berbeda nyata menurut uji BNT 5\%

Pada Tabel 1. terlihat perlakuan dosis kompos kulit bawang merah tidak berpengaruh nyata terhadapat tinggi tanaman pada umur 1 mst. Hal itu disebabkan bibit yang baru tumbuh masih menggunakan cadangan makanan yang tersedia pada bibit tersebut dan belum menggunakan nutrisi tambahan atau nutrisi pada kompos kulit bawang merah [9].

Tinggi tanaman sawi samhong terendah pada dosis kompos kulit bawang
Pengaruh Dosis Kompos Kulit Bawang Merah Terhadap Tinggi Tanaman

Pengukuran tinggi tanaman dilakukan sebanyak 5 kali dengan selang waktu 1 minggu sekali yaitu. Berdasarkan analisis sidik ragam (anova) bahwa dosis kompos kulit bawang merah tidak berpengaruh pada tinggi tanaman sawi samhong pada 1 MST, dan berpengaruh sangat nyata pada 2 MST, 3 MST, 4 MST dan 5 MST. Rata-rata tinggi tanaman sawi samhong dapat dilihat pada Tabel 1 . 
yang cukup berperan dalam mempercepat pertumbuhan tanaman secara keseluruhan, khususnya batang dan daun. Unsur hara tersebut terkandung dalam kompos kulit bawang merah yang digunakan dalam penelitian [8]. Jumlah Nitrogen yang tinggi dapat membantu pertumbuhan sawi samhong secara optimal. Pertambahan tinggi tanaman diakibatkan terbentuknya sel-sel yang terbentuk di daerah meristem apikal dan berarti aktifitas pembelahan dan pemanjangan sel di pucuk merupakan inti dari pertumbuhan tinggi tanaman [10], kelancaran aktifitas pertumbuhan dipucuk yang tergantung pada suplai faktor tumbuh terutama karbohidrat dari daun sebagai pusat fotosintesis. Sintesis karbohidrat terjadi pada bagian-bagian hijau tanaman, terutama bagian daun tanaman yang mendapat sinar matahari langsung, dengan menggunakan unsur hara yang diserap tanaman sebagai bahan baku. Tanaman untuk tumbuh optimal membutuhkan unsur hara Nitrogen yang merupakan unsur hara esensial yang berperan dalam pertumbuhan tanaman pada fase vegetatif. Unsur hara yang cukup diperlukan untuk menghasilkan tanaman yang optimal, sehingga bahan organik yang mengandung unsur hara mikro dan makro yang dibutuhkan tanaman [11].
Hal di atas menunjukkan bahwa kompos kulit bawang merah pada perlakuan D3 (1.500 gr) mampu menyuplai Nitrogen sesuai jumlah yang dibutuhkan untuk pertumbuhan dan perkembangan pada sawi samhong. Pertumbuhan sawi samhong yang tinggi dipengaruhi oleh nitrogen yang terkandung pada kompos kulit bawang merah merupakan unsur hara yang penting, kebutuhan unsur Nitrogen untuk tanaman lebih tinggi dibandingkan dengan unsur hara lainnya. Hal ini sejalan dengan pendapat unsur Nitrogen berfungsi dalam pertumbuhan vegetatif tanaman, Nitrogen merupakan unsur hara esensial untuk pembelahan dan perpanjangan sel, sehingga Nitrogen merupakan penyusun protoplasma yang banyak terdapat dalam jaringan seperti titik tumbuh tanaman [3].

Pengaruh Dosis Kompos Kulit Bawang Merah Terhadap Jumlah Daun

Bedasarkan analisis sidik ragam (anova) bahwa dosis kompos kulit bawang merah tidak berpengaruh nyata terhadap jumlah daun sawi samhong pada 1 MST, dan berpengaruh sangat nyata pada 2 MST, 3 MST, 4 MST dan 5 MST. Rata-rata jumlah daun sawi samhong dapat dilihat pada tabel 2. 
Tabel 2. Hasil Uji BNT Pengaruh Dosis Kompos Kulit Bawang Merah Terhadap Jumlah Daun

\begin{tabular}{lccccc}
\hline \multirow{2}{*}{ Perlakuan } & \multicolumn{5}{c}{ Jumlah Daun (Helai) } \\
\cline { 2 - 6 } & $1 \mathrm{MST}$ & $2 \mathrm{MST}$ & $3 \mathrm{MST}$ & $4 \mathrm{MST}$ & $5 \mathrm{MST}$ \\
\hline D0 (0 gr) & $4.2 \mathrm{a}$ & $5.3 \mathrm{a}$ & $6.0 \mathrm{a}$ & $7.0 \mathrm{a}$ & $7.7 \mathrm{a}$ \\
D1 (500 gr) & $4.2 \mathrm{a}$ & $6.3 \mathrm{~b}$ & $7.2 \mathrm{a}$ & $8.3 \mathrm{a}$ & $10.0 \mathrm{~b}$ \\
D2 (1.000 gr) & $4.2 \mathrm{a}$ & $6.3 \mathrm{~b}$ & $8.5 \mathrm{~b}$ & $11.0 \mathrm{~b}$ & $13.0 \mathrm{c}$ \\
D3 (1.500 gr) & $4.3 \mathrm{a}$ & $6.5 \mathrm{~b}$ & $8.7 \mathrm{~b}$ & $11.5 \mathrm{~b}$ & $13.7 \mathrm{c}$ \\
\hline
\end{tabular}

Keterangan : Angka-angka yang diikuti huruf yang sama pada kolom yang sama berarti tidak berbeda nyata menurut uji BNT 5\%

Pada Tabel 2. dapat dilihat terlihat perlakuan dosis kompos kulit bawang merah pada 1 minggu setelah taman tidak berbeda nyata. Hal ini dikarenakan pada masa umur tersebut tanaman sawi samhong masih belum berkembang dan penyerapan unsur hara belum optimal. Bibit yang baru tumbuh masih menggunakan cadangan makanan yang tersedia pada bibit tersebut dan belum menggunakan nutrisi tambahan atau nutrisi pada kompos kulit bawang merah [9].

Berdasarkan Tabel 2. disimpulkan bahwa perlakuan berpengaruh sangat nyata pada 2 MST sampai 5 MST. Jumlah daun sawi samhong terbanyak pada dosis kompos kulit bawang merah D3 (1.500 gr) dengan jumlah daun 13,7 helai pada umur 5 MST. Jumlah daun sawi samhong terendah pada dosis kompos kulit bawang merah DO (0 gr) dengan jumlah daun 7.7 helai pada umur 5 MST. Dosis kompos daun bawang merah yang tepat akan menghasilkan pertumbuhan vegetatif yang optimal. Kompos daun bawang merah memiliki fungsi sebagai sumber Nitrogen bagi tanah yang berperan untuk memperbaiki sifat fisik, kimia, dan biologis tanah.

Selain itu, unsur hara Nitrogen dapat meningkatkan pertumbuhan vegetatif tanaman, dimana tanaman yang tumbuh pada media tanam yang cukup Nitrogen, berwarna lebih hijau. [12]. Pemberian perlakuan dosis kompos kulit bawang merah pada tanaman selada dan terung yang diberikan belum berpengaruh nyata terhadap tinggi tanaman dan jumlah daun terung maupun tinggi tanaman selada [8], namun hal ini tidak berlaku pada perlakuan dosis kompos bawang merah terhadap pertumbuhan sawi samhong.

Pemberian Nitrogen pada dosis yang tepat akan meningkatkan pertumbuhan tanaman, meningkatkan metabolisme tanaman, pembentukan protein, karbohidrat, sehingga berpengaruh pada pertumbuhan dan produksi tanaman meningkat [11]. Kekurangan nitrogen akan menyebabkan tanaman tidak tumbuh secara optimum dan 
berdampak menghambat atau tinggi tanaman, karena semakin tinggi menghentikan pertumbuhan tanaman. tanaman semakin banyak daun yang Kelebihan nitrogen menghasilkan tunas terbentuk [2].

muda yang lembek/lemah dan vegetatif, mengasamkan reaksi tanah, menurunkan $\mathrm{pH}$ tanah, merugikan tanaman karena akan mengikat unsur hara lain sehingga akan sulit diserap tanaman, dan pemupukan jadi kurang efektif dan tidak efesian. Nitrogen diambil oleh tanaman dalam bentuk ion amonium ( $\mathrm{NH} 4+$ ) dan ion nitrat (NO3-) yang terdapat dalam larutan tanah [12]. Jumlah daun sangat erat hubungannya dengan

\section{Pengaruh Dosis Kompos Kulit Bawang Merah Terhadap Lebar Daun \\ Bedasarkan analisis sidik ragam (anova) bahwa dosis kompos kulit bawang merah tidak berpengaruh nyata pada lebar daun sawi samhong pada 1 MST dan 2 MST serta berpengaruh sangat nyata pada 3 MST, 4 MST dan 5 MST. Rata-rata lebar daun sawi samhong dapat dilihat pada Tabel 3.}

Tabel 3. Hasil Uji BNT Pengaruh Dosis Kompos Kulit Bawang Merah Terhadap Lebar Daun

\begin{tabular}{llllll}
\hline \multirow{2}{*}{ Perlakuan } & \multicolumn{5}{c}{ Lebar Daun (cm) } \\
\cline { 2 - 6 } & $1 \mathrm{MST}$ & $2 \mathrm{MST}$ & $3 \mathrm{MST}$ & $4 \mathrm{MST}$ & $5 \mathrm{MST}$ \\
\hline D0 (0 gr) & $1.7 \mathrm{a}$ & $2.4 \mathrm{a}$ & $4.5 \mathrm{a}$ & $6.2 \mathrm{a}$ & $6.8 \mathrm{a}$ \\
D1 (500 gr) & $1.7 \mathrm{a}$ & $2.4 \mathrm{a}$ & $5.8 \mathrm{~b}$ & $9.0 \mathrm{~b}$ & $9.8 \mathrm{~b}$ \\
D2 (1.000 gr) & $1.7 \mathrm{a}$ & $2.5 \mathrm{a}$ & $6.3 \mathrm{~b}$ & $9.3 \mathrm{~b}$ & $11.5 \mathrm{c}$ \\
D3 (1.500 gr) & $1.7 \mathrm{a}$ & $2.6 \mathrm{a}$ & $7.0 \mathrm{c}$ & $11.5 \mathrm{c}$ & $13.7 \mathrm{~d}$ \\
\hline
\end{tabular}

Keterangan : Angka-angka yang diikuti huruf yang sama pada kolom yang sama berarti tidak berbeda nyata menurut uji BNT 5\%

Namun pada 3 MST, 4 MST dan 5 MST

Berdasarkan data pada Tabel 3. Pada 1 dan 2 MST, untuk semua dosis tidak berpengaruh nyata. Hal ini disebabkan bibit yang baru tumbuh masih menggunakan cadangan makanan yang tersedia pada bibit tersebut dan belum menggunakan nutrisi tambahan atau nutrisi pada kompos kulit bawang merah [9]. Pada umur 1-2 mst lebar daun sawi samhong masih beradaptasi dengan lingkungan. perlakuan dosis kompos bawang merah berpengaruh sangat nyata terhadap lebar daun. Lebar daun sawi samhong tertinggi dengan dosis kompos kulit bawang merah D3 (1.500 gr) $13,7 \mathrm{~cm}$ pada umur 5 MST. Lebar daun sawi samhong terendah dengan dosis kompos kulit bawang merah DO (0 gr) 6,8 cm pada umur 5 MST. Hal ini menyatakan apabila unsur Nitrogen tersedia dengan tepat akan menghasilkan protein 
yang tinggi sehingga meningkatkan lebar daun. Ketersediaan unsur hara pada tanah berpengaruh dalam proses pembentukan daun, terutama unsur Nitrogen dan Fosfat [3].

Proses pembentukan daun tidak terlepas dari peranan unsur hara seperti Nitrogen dan Fosfor yang terdapat pada medium tanah serta dalam kondisi tersedia bagi tanaman [13]. Jumlah protein yang terbentuk semakin banyak dan akan menambah jumlah protoplasma pada sel tanaman dan akhirnya akan menambah lebar daun yang kaya akan klorofil. Jika kandungan hara cukup tersedia maka pertumbuhan daun suatu tanaman akan semakin tinggi, dimana sebagian besar asimilat dialokasikan untuk pembentukan daun yang mengakibatkan lebar daun bertambah [11].

\section{Pengaruh Dosis Kompos Kulit Bawang Merah Terhadap Panjang Daun}

Berdasarkan analisis sidik ragam (anova) bahwa dosis kompos kulit bawang merah tidak berpengaruh nyata terhadap panjang daun sawi samhong pada 1 MST, dan berpengaruh sangat nyata pada 2 MST, 3 MST, 4 MST dan 5 MST. Rata-rata panjang daun sawi samhong dapat dilihat pada Tabel 4.

Tabel 4. Hasil Uji BNT Pengaruh Dosis Kompos Kulit Bawang Merah Terhadap panjang Daun

\begin{tabular}{llllll}
\hline \multirow{2}{*}{ Perlakuan } & \multicolumn{5}{c}{ Panjang Daun $(\mathrm{cm})$} \\
\cline { 2 - 6 } & $1 \mathrm{MST}$ & $2 \mathrm{MST}$ & $3 \mathrm{MST}$ & $4 \mathrm{MST}$ & $5 \mathrm{MST}$ \\
\hline D0 (0 gr) & $2.2 \mathrm{a}$ & $4.5 \mathrm{a}$ & $6.7 \mathrm{a}$ & $10.3 \mathrm{a}$ & $13.3 \mathrm{a}$ \\
D1 (500 gr) & $2.3 \mathrm{a}$ & $5.1 \mathrm{~b}$ & $9.0 \mathrm{~b}$ & $14.2 \mathrm{~b}$ & $18.7 \mathrm{~b}$ \\
D2 (1.000 gr) & $2.4 \mathrm{a}$ & $5.3 \mathrm{~b}$ & $10.0 \mathrm{~b}$ & $16.3 \mathrm{c}$ & $22.7 \mathrm{c}$ \\
D3 (1.500 gr) & $2.6 \mathrm{a}$ & $5.3 \mathrm{~b}$ & $12.0 \mathrm{c}$ & $18.0 \mathrm{~d}$ & $24.2 \mathrm{c}$ \\
\hline
\end{tabular}

Keterangan : Angka-angka yang diikuti huruf yang sama pada kolom yang sama berarti tidak berbeda nyata menurut uji BNT 5\%.

Rata-rata panjang daun sawi samhong dapat dilihat pada Tabel 4. Pada awal penanaman, untuk semua dosis kompos bawang merah tidak berbeda nyata. Hal itu disebabkan bibit yang baru tumbuh masih menggunakan cadangan makanan yang tersedia pada bibit tersebut dan belum menggunakan nutrisi tambahan atau nutrisi pada kompos kulit bawang merah [9].

Bedasarkan Tabel 4. pada umur 5 MST dosis yang terbaik untuk panjang daun yaitu D3 (1.500 gr) dengan panjang daun $24,2 \mathrm{~cm}$ dan panjang daun terendah yaitu DO (0 gr) dengan panjang daun $13,3 \mathrm{~cm}$. Unsur Nitrogen yang cukup sehingga meningkatkan 
panjang daun. Pertumbuhan panjang daun dipengaruhi oleh unsur Nitrogen dan Fospor. Kedua unsur tersebut didapatkan dari penambahan kompos kulit bawang merah [3].

Apabila unsur Nitrogen tersedia dengan tepat akan menghasilkan protein yang tinggi. Pertumbuhan daun akan cepat berubah dan dapat mempercepat pertumbuhan vegetatif tanaman karena dengan penyerapan hara Nitrogen akan dapat meningkatkan pembentukan dan pertumbuhan daun pada tanaman [14].

\section{Pengaruh Dosis Kompos Kulit Bawang} Merah Terhadap Berat Basah Tanaman

$$
\text { Bedasarkan analisis sidik ragam }
$$
(anova) bahwa dosis kompos kulit bawang merah berpengaruh sangat nyata terhadap berat basah tanaman dan dapat dilihat pada Tabel 5.

Tabel 5. Hasil Uji BNT Pengaruh Media Tanam Terhadap Berat Basah Tanaman

\begin{tabular}{lc}
\hline Perlakuan & Berat Basah Tanaman (g) \\
\hline D0 (0 gr) & $20.0 \mathrm{a}$ \\
D1 (500 gr) & $40.0 \mathrm{a}$ \\
D2 (1.000 gr) & $77.7 \mathrm{~b}$ \\
D3 (1.500 gr) & $101.7 \mathrm{~b}$ \\
\hline
\end{tabular}

Keterangan : Angka-angka yang diikuti huruf yang sama pada kolom yang sama berarti tidak berbeda nyata menurut uji BNT 5\%

Berat basah sawi samhong merupakan total berat tanaman yang terdiri dari panjang tangkai daun, tinggi tanaman, panjang daun dan jumlah daun yang menujukkan adanya aktivitas metabolik tanaman. Semakin tinggi hasil dari komponen pertumbuhan, maka berat basah tanaman juga akan semakin meningkat. Berdasarkan hasil uji BNT 5\% pada Tabel 5. menunjukkan bahwa perlakuan dosis kompos kulit bawang merah D3 (1.500 gr) memberikan bobot basah paling optimal dengan bobot 101,67 gram dan bobot basah terendah terdapat pada dosis DO (0 gr) dengan bobot 20 gram. Berdasarkan tabel 4 . menunjukkan bahwa pada perlakuan dosis kompos kulit bawang merah memberikan pengaruh sangat nyata pada rata-rata bobot basah. Hal ini disebabkan kandungan air dan unsur hara yang terdapat pada daun cukup optimal sehingga mengakibatkan bobot segar tanaman tertinggi.

Untuk mencapai bobot segar tanaman yang optimal, tanaman masih membutuhkan banyak energi maupun unsur hara agar peningkatan jumlah maupun ukuran sel 
dapat mencapai optimal serta memungkinkan adanya peningkatan kandungan air tanaman yang optimal pula, sebagian besar bobot segar tanaman disebabkan oleh kandungan air [15]. Air sangat berperan dalam turgiditas sel, sehingga sel-sel daun akan membesar [3], membagi status nutrisi dalam jaringan tanaman dan pertumbuhan tanaman yaitu, zona defisiensi dan zona cukup. Dizona defisiensi, penambahan nutrisi berakibat meningkatkan produksi berat tanaman sedangkan di zona cukup, penambahan nutrisi berakibat meningkatkan kandungan unsur hara dalam jaringan tanaman tetapi tidak ada peningkatan hasil panen. Adanya unsur Nitrogen akan meningkatkan pertumbuhan bagian vegetatif seperti daun, batang, cabang dan akar [16].

Sekitar $80 \%$ sampai $85 \%$ dari berat basah herba (tumbuhan tidak berkayu) adalah air, dan sebagian besar tumbuhan tumbuh dengan cara mengakumulasi air di dalam vakuola tengah sel-selnya [17]. Selain itu air sesungguhnya dapat dianggap sebagai nutrien karena air menyediakan sebagian besar atom hidrogen dan beberapa atomatom oksigen yang digabungkan dalam senyawa organik pada peristiwa fotosintesis. Namun demikian, hanya sebagian kecil saja dari air yang masuk ke dalam suatu tumbuhan yang menyumbangkan atom kepada molekul organik. Umumnya lebih dari $90 \%$ air yang diserap oleh tumbuhan hilang melalui transpirasi, dan sebagian besar dari air yang dipertahankan tumbuhan ternyata berfungsi sebagai bahan pelarut, memungkinkan terjadinya pemanjangan sel, dan bertugas mempertahankan bentuk jaringan yang lunak dengan cara menjaga sel-sel agar tetap turgid. Kemampuan tanaman dalam menyerap air terletak pada akarnya. Akar merupakan organ vegetatif utama yang memasok air, mineral dan bahan-bahan yang penting untuk pertumbuhan dan perkembangan tanaman. Kondisi akar yang baik akan mendukung penyerapan air yang optimal.

\section{KESIMPULAN}

Terdapat pengaruh nyata mulai minggu kedua setelah tanam terhadap semua variabel, tinggi tanaman, jumlah daun, lebar daun, panjang daun dan bobot basah. Dosis kompos kulit bawang merah terbaik pada dosis D3 (1.500 gr) terhadap semua variabel, tinggi tanaman, jumlah daun, lebar daun, panjang daun dan bobot basah.

\section{DAFTAR PUSTAKA}

Hartus, T., 2018. Berkebun Hidroponik Secara Murah. Penebar Swadaya, Bogor.

Fahrudin, F. 2017. Budidaya Caisim Menggunakan Ekstrak Teh dan Pupuk Kascing. (Skripsi). Surakarta : Universitas Sebelas Maret.

Erawan, D., Yani OW., dan Bahrun A. 2013. Pertumbuhan dan Hasil Tanaman Sawi (Brassica Juncea L.) pada Berbagai Dosis 
Pupuk Urea. Jurnal AGROTEKNOS. Vol. 3No. 1.

Triyono, A. 2013. Efisiensi Penggunaan Pupuk $-\mathrm{N}$ Untuk Pengurangan Kehilangan Nitrat Pada Lahan Pertanian. Jurnal Sumber Daya Lingkungan. Vol 8 No. 1.

Supartha, I Nyoman Yogi.; Gede Wijana.; Gede Minaka Adnyana. 2012. Aplikasi jenis pupuk organik pada tanaman padi sitem pertanian organik, E-Jurnal Agroekoteknologi Tropika Vol.1, No.2 Universitas Udayana

Lestari, B.K. 2016. Pengaruh Kombinasi Pupuk Kandang Sapi dan Abu Sabut Kelapa sebagai Pupuk Utama dalam Budidaya Tanaman Brokoli (Brassica oleracia L.). Journal of Agro Science.

Budiana. N.S. 2018. Hidroponik Sayuran. Jakarta: Penebar Swadaya.

Banu, L.S., dan Sholihah, S.M., 2021. Efektivitas Pemberian Beberapa Dosis Kompos Kulit Bawang Merah Terhadap Serapan Hara Pada Polikultur Selada Dan Terung. Jurnal IImiah Respati, 12 (1).

Lingga, P. dan Marsono. 2017. Petunjuk Penggunaan Pupuk. Edisi Revisi Penebar Swadaya. Jakarta.

Yikwa, P. dan L.S. Banu. 2020. Respon Polikultur Cabai Rawit dan Sawi terhadap Waktu Pengomposan dan Dosis Kompos Kulit Bawang Merah. Jurnal Ilmiah Respati, 11 (1).
Lakitan, B. 2018. Dasar-dasar Fisiologi Tumbuhan. PT Raja Grafindo Persada. Jakarta

Raharjo M dan ER. Pribadi. 2013. Pengaruh Pupuk Urea, SP36 dan KCl Terhadap Pertumbuhan dan Produksi Temulawak (Curcuma Xanthorhiza Roxb). Jurnal Littri 16 (3) : 98- 105.

Nyapka Yusup M, Lubis M.A, Pulung Anwar Mamat, Amrah Ghaffar A, Munawar Ali, Hong Ban Go, Hakim Nurhajati. 2018. Kesuburan tanah. Universitas Lampung. Palembang.

Fatma DM. 2016. Pengaruh Pemberian Pupuk Organik Terhadap Pertumbuhan dan HasilTanaman Sawi Caisim. Agronobis 1(1): 8-98.

Lahadassy. J., A.M Mulyati dan A.H Sanaba. 2017. Pengaruh Konsentrasi Pupuk Organik Padat Daun Gamal terhadap Tanaman Sawi, Jurnal Agrisistem, 3 (6) :51-55.

Jumin H.B. 2012.Agroteknologi Suatu PendekatanFisiologi Tumbuhan. Raja Grafindo Persada. Jakarta.

Campbell, N. A., J. B. Reece dan L. G. Mitchell., 2012. Biology. Erlangga, Jakarta. 